\title{
Structure-functional characterization of cytochrome P4502E1 (CYP2E1)
}

\author{
I. M. Danko, N. A. Chaschin
}

Institute of Molecular Biology and Genetics, National Academy of Sciences of Ukraine 150, Acad. Zabolotny Str., Kyiv, 03143, Ukraine

irinad45@mail.ru

\begin{abstract}
This review summarizes data on expression level and localization, structure and functional properties of cytochrome P4SO2EI (CYP2E1). Induction of CYP2EI synthesis and activity by compounds with various chemical structures and under certain pathophysiological states is considered. Special emphasis is placed on CYP2EI expression inhibitors. The latest data on CYP2EI expression regulation and degradation mechanisms are analyzed.
\end{abstract}

Keywords: cytochrome P4502EI (CYP2EI), expression, inductors and inhibitors, expression regulation, oxidative metabolism of ethanol.

Introduction. Monooxygenase cytochrome P450-dependent system of microsomal haemoproteins is associated with endoplasmic reticulum membrane, plays an important role in the metabolism of a broad spectrum of both endogenous and exogenous compounds with different chemical structure and regulates their transformation to soluble and less toxic metabolites. Cytochromes $\mathrm{P} 450$ perform a diverse set of monooxygenation reactions including hydroxylation, epoxidation, demethylation and heteroatom oxidation. Mammalian CYP450s are responsible for metabolism of most diverse xenobiotics - drug molecules, environmental compounds and pollutants, and are required for the efficient elimination of foreign chemicals from the body.

On the other hand, these enzymes also metabolically activate biologically inert compounds to electrophilic derivatives that can cause toxicity, cell death and cellular transformation resulting in cancer. Cytochrome P450 monooxygenases are also involved in physiologically important pathways of synthesis of

I. M. DANKO, . N. A. ChASCHIN, 2007 steroid hormones, prostaglandins and vitamins. All P450 enzymes exhibit similarity in their structure and general mechanism of action; however, there are significant differences in the detailed function of individual enzymes as well as in the structures and properties of their active sites. Specific forms of P450 exhibit distinct, but partially overlapping substrate specificities [1]. The hepatic cytochrome P450 system, with numerous different $\mathbf{P 4 5 0}$ enzymes, is characterized by its inducibility by a variety of endogenous and exogenous compounds.

Cytochrome P4502E1 (CYP2E1) description. Cytochrome P4502E1 (CYP2E1) is a specific induced by ethanol isozyme of cytochrome P450. Human CYP$2 E 1$ gene is located on the $10^{\text {th }}$ chromosome $(10 \mathrm{q} 24.3-$ qter), consists of 9 exones and 8 intrones, contains a typical TATA-box and spans 11413 base pairs of genomic DNA [2, 3]. Only one gene has been detected in the CYP2E subfamily in rat, mouse and man, while two genes were found in rabbit [2]. Human CYP2E1 is a membrane-bound protein with molecular weight of $\sim 57 \mathrm{kDa}$. It consists of 493 amino acid residues and is primarily associated with 
endoplasmic reticulum membranes [4]. CYP2E1 is well conserved across mammalian species $[5]$ and has been isolated and purified from the liver of many mammals including rabbit, rat, mouse, hamster, monkey and humans $[6,7]$. The complete amino acid sequences were determined for rat and human CYP2E1 [6]. Both proteins contain 493 amino acids and calculated molecular masses of 56,634 and $56,916 \mathrm{Da}$, respectively. Human CYP2El shared $75 \%$ nucleotide and $78 \%$ amino acid similarities to the respective orthologous rat cDNA and deduced amino acid sequences [6]. Amino acid composition of CYP2E1 is similar to that of other cytochrome P450 isozymes: $38 \%$ hydrophobic, $13 \%$ basic and $12 \%$ acidic. Protein contains five Trp and four Cys residues [8]. The greater part $(63.7 \%)$ of CYP2El molecule has regular structure $-\alpha$-helices of different length form $52.5 \%$ of amino acid sequence, and $\beta$-sheets constitute $11.2 \%$ [9].

CYP2E1 three-dimensional structure is studied insufficiently due to the presence of hydrophobic $\mathrm{N}$-terminal transmembrane anchor in the structure of all cytochrome $\mathrm{P} 450$ isoforms, and hydrophobic amino acid residues on the protein surface, that leads to molecule aggregation in water solutions. The latter complicates crystallization of protein and definition of a three-dimensional structure by $\mathrm{X}$-ray analysis. Three-dimensional structure models of CYP2E1 are constructed for the purpose of structure-based prediction of CYP2E1 metabolism of diverse substrates [10]. To establish a three-dimensional structure of proteins that are difficult to dissolve in water solutions, molecular modelling technique is widely utilized. This approach includes search for the protein with known crystal structure with a relatively high degree of primary sequence homology with protein in question, and utilizing this protein as a template. Models of tertiary structure of human CYP2E1 were developed on the basis of CYP2E1 sequence alignments with crystallographic templates of known structure, including rabbit CYP2C5 $[10,11]$, human CYP2C9 [9] and bacterial CYP102 [4]. Alignment of CYP2E1 spatial structure model with structures of CYP2C5 and CYP2C9 template proteins is presented in Figure [9]. A relatively high degree of primary sequence homology (identity $=59 \%$ ), as expected for proteins of the same CYP family, ensured a straightforward generation of the three-dimensional model due to relatively few deletions and insertions of amino acid residues with respect to the CYP2C5 crystal structure [10]. Following geometric and energetic assessments, the utility of the model was tested in structure-based predictions of metabolism. Interactive docking of a number of human CYP2E1 substrates: chlorzoxazone, p-nitrophenol, $\mathrm{N}$-nitrosodimethylamine, acetaminophen, caffeine, theophylline, and methoxyfluranis is consistent with their known positions in CYP2E1-mediated metabolism, where specific interactions with key active site amino acid side-chains appear to rationalize the binding and orientation of substrate molecules. The sequence alignment of human CYP2E1 revealed a relatively high degree of homology with mouse, rat and rabbit CYP2E1 (80.8, 80.3 , and $79.0 \%$ ) and indicated similarity of $\mathbf{9 0 . 0}$, 92.0 , and $90.0 \%$, respectively. The heme is placed between helix $\mathrm{L}$ on the side of the heme proximal to the surface of the protein and helix I in the interior of the protein. Coordination of heme iron by cysteine plays a prominent role in the CYP2E1 capacity to catalyze the scission of molecular oxygen bound to the sixth coordination site of the heme iron [11].

Little information is available on the active site topologies of the enzyme. Previously, it was suggested that the active site was restricied due to the limited size of known substrates. A model for the active site structure of human CYP2E1 based on the coordinates of cytochrome P450BM-3 crystal structure was proposed. The predicted CYP2EI active site model shows that the active site is small and contains mainly hydrophobic residues [12]. The active site of human CYP2E1 is sterically unhindered directly above the iron for a distance of $10 \AA$. The substrate binding pocket is located on top of pyrrole rings $A$ and $D$ of the heme and the active site cavity is relatively open above pyrrole rings $A$ and $D[13]$. The access to $B$ and $C$ rings is partially or completely blocked by protein side chains. The substrate binding cavity has a volume of $4717 \mathrm{~A}^{3}$.

Amino acid residues within the putative active site of human CYP2E1, including those associated with the binding of substrates and inhibitors, are shown to correspond with those identified by sitedirected mutagenesis experiments [14]. Certain CYP2E1 amino acid residues were identified, which participate in the binding of substrates and inhibitors chlorzoxazone, p-nitrophenol, $\mathrm{N}$-nitrosodimethylamine, acetaminophen, caffeine, and theophylline. Molecular modelling of a predicted cytosolic domain of CYP2E1 resulted in identification of a putative ubiquitination-target/substrate-interaction structure (re- 


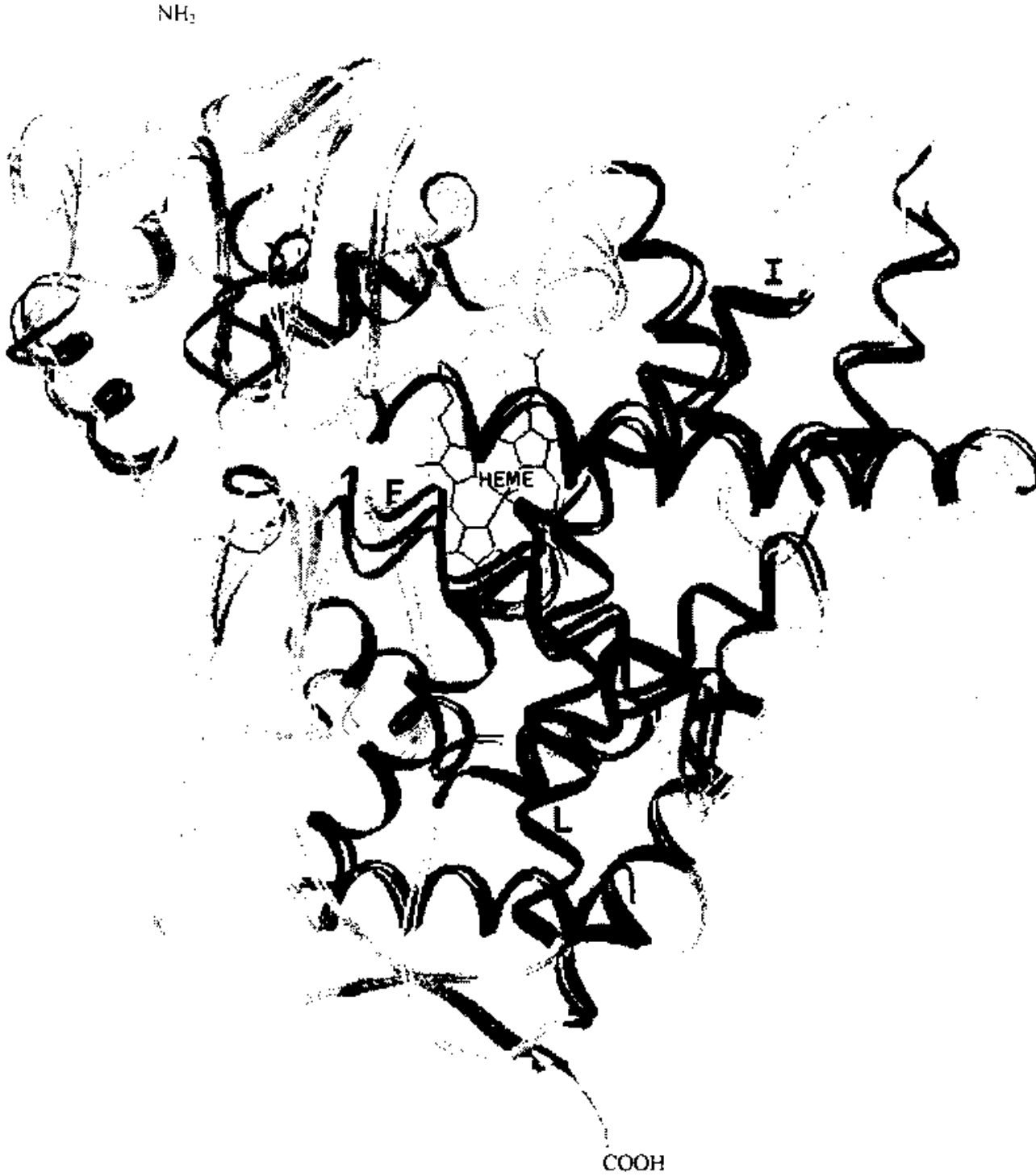

Alignment of CYP2E1 spatial structure model with structures of CYP2C5 and CYP2C9 template proteins based on locations of $\mathbf{C}_{a}$ atoms in their polypeptide irames. $a$-Helices are shown in black, $\beta$-folds - in dark grey, and polypeptide chain isregular sites - in grey. $a$-Helices participating in active site formation are also highlighted separately. Threedimensional structure model of human CY2E1 was constructed using the Web-servers ESyPred3D and Swiss-Model. This figure was prepared using Swiss-PDB Viewer 3.7 software [9]

sidues 317-340) [15]. Consequently, it was found that the CYP2E1 active site exhibits complementarity with the structural characteristics of known substrates and inhibitors of this enzyme, including their relatively low molecular weights and disposition of hydrogen bond-forming groups [4].

The expression and localization of CYP2E1. CYP2E1 is a clinically and toxicologically important isozyme and is constitutively expressed in the liver and many extrahepatic tissues [7, 16-18]. Using specific antibodies in immunoblots and RT-PCR mRNA analysis it was shown that CYP2E1 expression level is significantly lower in extrahepatic tissues, in particular, kidney, pancreas, lung, nasal and intestinal mucosa, as well as in distinct brain and heart regions $[7,17-22]$. There also appear to be significant sex differences in the expression of CYP2E1. In particular, it was demonstrated that CXP2E1 expressed in higher levels in male as compared to female rats $[23]$.

Recent studies employing immunohistochemical techniques and Western blot analysis have shown that constitutive expression of CYP2EI protein is predominantly restricted to the perivenous region of the liver acinus [7, 16]. Microsomes isolated from the pericentral region of the liver display increased content of CYP2EI and elevated catalytic activity towards effective substrates for CYP2E1 such as $\mathrm{N}$ dimethylnitrosamine, as compared with periportal microsomes [24]. Immunohistochemical analysis re- 
vealed a 30-fold higher concentration of CYP2E1 in the centrilobular than in the periportal regions of the rat liver [25]. Results from in situ hybridization and run off experiments indicate that this regioselectivity is caused by a higher rate of gene transcription in the perivenous hepatocytes [16]. Quantitative image analysis demonstrated that CYP2E1 mRNA transcripts content in perivenous hepatocytes was significantly higher than in midzonal and periportal cells $(18.3 \pm 1$; $9.5 \pm 2$ and $3.1 \pm 2$ ), respectively [26]. The heterogeneous distribution of CYP2E1 was also observed in cells isolated from either region and correlated to the relative content of CYP2E1 mRNA in the two cell types [25]. CYP2E1 transcription level appears to be activated by factors that are selectively expressed in the perivenous hepatocytes [16].

CYP2E1 catalytic activity in certain liver regions also varies significantly. Low $\mathrm{K}_{\mathrm{m}}$ dimethylnitrosamine demethylase activity (but not high $K_{m}$ activity) as well as the oxidation of aniline and p-nitrophenol was 2to 3-times higher in pericentral compared to periportal microsomes. Oxidation of aniline and p-nitrophenol was elevated in pericentral hepatocytes compared with periportal hepatocytes to the same extent as in the isolated microsomes [24]. The regiospecific expression, induction and increased catalytic activity of CYP2E1 may explain why several hepatotoxins, known to be metabolized by this isozyme, primarily damage the centrilobular region in the liver $[25,27]$. Tissue-specific differences in CYP2E1 expression can affect extrahepatic toxicity or carcinogenicity because of chemical activation of xenobiotics in target areas [19].

In hepatocytes CYP2E1 is predominantly associated with endoplasmic reticulum membrane. Low levels of CYP2E1 are expressed in many other hepatocyte compartments: in mitochondria, Golgi apparatus, lysosomal vesicles and in the plasma membrane $[28,29]$.

The biochemical and toxicological properties of CYP2E1. Humans are exposed to over 70000 manmade chemicals including drugs, food additives, herbicides, pesticides, and industrial agents. It is well established that environmental chemicals are the cause of numerous human diseases including cancer. In most cases, chemical carcinogens require metabolic activation, which is mainly achieved by cytochrome P450 enzymes. CYP2E1 is responsible for metabolism of most xenobiotics, reduces toxicity of exogenous compounds, and is required for the efficient elimi- nation of foreign chemicals from the body [30]. Alterations in the level of CYP2E1 might influence the health effects of the environmental pollutants [31]. DNA modification and cancers can result from exposure to endogenous and exogenous chemicals and their metabolism to non-covalently bound products [32]. Most of the CYP2El-catalyzed reactions are oxidations $[30,33,34]$. CYP2E1 is involved in metabolism of more than 100 endogenous and exogenous low-molecular hydrophobic toxicologically dangerous compounds with different structures: a wide variety of therapeutic agents, protoxicants and procarcinogens, and low molecular weight solvents [7, $15,17,35]$. This enzyme is responsible for the bioactivation and detoxification of a variety of xenobiotics present in food, organic solvents, tobacco smoke, drugs, pesticides, environmental pollutants and alcoholic drinks [36]. Alcohols, especially ethanol, were the first substrates to be characterized for oxidation by the microsomal ethanol oxidizing system [37]. CYP2E1 substrates include several alcohols, aldehydes, ketones, ethers, aromatic compounds, halogenated hydrocarbons, alkanes, alkenes, and fatty acids. CYP2E1-catalyzed metabolism may cause toxicity or DNA damage through the production of toxic metabolites, oxygen radicals, and lipid peroxidation [38 ]. For example, it was demonstrated that CYP2E1 is the major determinant of in vivo benzene metabolism and benzene-induced myelotoxicity in mice [39].

CYP2E1 is involved in the process of oxidative transformation not only in detoxification, but also in metabolic bioactivation of many substrates, thus being of importance in the activation of many chemicals to cytotoxic, mutagenic or carcinogenic products $[7,40]$. It contributes to activation of many procarcinogens and several drugs to highly reactive metabolites [7, $17,30,32,33,38$ ]. CYP2E1 participates in $a-C-$ hydroxylation, $\omega$-hydroxylation, $\mathrm{N}$-dealkylation of nitrosamine derivatives including $\mathrm{N}$-nitrosodialkylamines and tobacco-smoke-related nitrosamines in human liver microsomes [41]. In particular, the tobacco carcinogens 4-(methylnitrosamino)-1-(3-pyridyl)-1-butanone and $\mathrm{N}$-nitrosonornicotine require $a$-carbon hydroxylation in order to exert their carcinogenic effects. The tobacco carcinogen 4-(methylnitrosamino)-1-(3-pyridyl)-1-butanone is enzymatically activated by the hydroxylation of the $\alpha$-methyl and $\alpha$-methylene groups, leading to the formation of reactive products which can pyridyloxobutylate and methylate DNA, respectively [42]. CYP2E1 is invol- 
ved in the bioactivation of various other compounds present in tobacco smoke, for example, acrolein and 1,3-butadiene [20]. CYP2E1 enzyme is a major catalyst for metabolic activation of $\mathrm{N}$-nitrosodialkylamines involved in $\mathrm{N}$-demethylation of nitrosoamines $-\mathrm{N}$-nitrosodimethylamine, $\mathrm{N}$-nitrosomethylamine and $\mathrm{N}$-nitrosoethylamine - to toxic, mutagenic and carcinogenic metabolites. The activation of $\mathrm{N}$ nitrosodimethylamine and $\mathrm{N}$-nitrosonornicotine by liver microsomes was suggested to be catalyzed more actively by CYP2E1 than by other P450 enzymes because the activities were well correlated with $\mathrm{N}$ nitrosodimethylamine $\mathbf{N}$-demethylation and aniline p-hydroxylation in human hepatocytes [41].

Liver microsomes from control rats metabolize at variable metabolic rates eight $\mathrm{N}$-nitrosodi-n-alkylamines, including five symmetrical ( $\mathrm{N}$-nitroso-dimethyl, -diethyl, -dipropyl, -dibutyl and -diamylamines) and four asymmetrical (N-nitrosomethylethyl, methylpropyl, methylbutyl, and methylamylamines), into aldehydes. The longer the alkyl chain of symmetrical $\mathrm{N}$-nitrosamines, the smaller was the metabolic rate of the corresponding aldehyde formation [43]. The human liver microsomes also catalyzed the dealkylation and denitrosation of other nitrosamines examined. The rates of product formation and the ratios of denitrosation to dealkylation varied with the structures and concentrations of the substrates as well as with the microsomal samples tested [44]. At a concentration of $0.2 \mathrm{mM} \mathrm{N}$-nitrosodimethylamine, the rates of denitrosation (nitrite formation) were 5 to $10 \%$ of those of demethylation (formaldehyde formation); the ratio of denitrosation to demethylation increased with increases in $\mathrm{N}$-nitrosodimethylamine concentration. The rates of product formation of the samples ranged from 0.18 to 2.99 nmol formaldehy$\mathrm{de} \cdot \mathrm{min}^{-1} \cdot \mathrm{mg}^{-1}$ microsomal protein (median, 0.53 nmol) [44].

Purified human liver CYP2E1 and human liver microsomes catalyzed the rearrangement of 2,6-dimethylaniline to 4-amino-3,5-dimethylphenol. It is indicated by the occurrence of hemoglobin adducts of 2,6-dimethylaniline [45].

It was found that CYP2E1 is the only enzyme responsible for epoxidation of acrylonitrile - suspected human carcinogen. It is demonstrated that CYP2E1-mediated oxidation is a prerequisite for acrylonitrile metabolism to cyanoethylene oxide or cyanide formation, and this pathway is exclusively catalyzed by CYP2E1. It is confirmed that cyanide plays an essential role in the causation of the acute toxicity/mortality of acrylonitrile [46].

CYP2E1 also plays an important role in omegaand (omega-1)-hydroxylations of fatty acids. Three parameters were studied: alkyl chain length, presence and configuration of double bond(s) in the alkyl chain, and involvement of carboxylic function in the fatty acid binding inside the access channel of P450 active site. The total rate of metabolite formation decreased when increasing the alkyl chain length of saturated fatty acids from $\mathrm{C} 12$ to $\mathrm{C} 16$. The double bond configuration did not modify the ability of fatty acid hydroxylation significantly. However, unsaturated fatty acids, such as oleic, elaidic and linoleic acids, were omega- and (omega-1)-hydroxylated with efficiency at least similar to palmitic acid [47].

CYP2E1 is involved in metabolism of two hepatotoxic solvents $-\mathrm{N}, \mathrm{N}$-dimethyl- and $\mathrm{N}, \mathrm{N}$-diethylformamide. In the $\mathrm{N}, \mathrm{N}$-dimethylformamide metabolism the role of CYP2E1 is crucial and its expression may be an important factor in determining the susceptibility of humans to this solvent [48]. Moreover, CYP2E1 plays a major role in activation of other procarcinogenes such as benzene, urethane and styrene [49].

CYP2E1 also catalyzes the oxidation of low density lipoproteins. It is well established that low density lipoprotein oxidation is a major contributor to foam cell formation during early atherogenesis. It was concluded that low density lipoproteins can be oxidized by CYP2E1. Due to their presence in arterial wall, their oxidation may have a physiopathological relevance to atherogenesis [50]. In addition to the rather classical oxidations, P450s also catalyze less generally discussed reactions including reduction, desaturation, ester cleavage, ring expansion, ring formation, aldehyde scission, dehydration, ipso attack, one-electron oxidation, coupling reactions, rearrangement of fatty acid and prostaglandin hydroperoxides, and phospholipase activity [33].

Metabolism of drugs by CYP2E1. CYP2E1 is involved in oxidative metabolism of clinically important drugs: acetaminophen, caffeine, chlorzoxazone, anaesthetics (enflurane, halothane, sevoflurane) [5, $17,27,51$ ]. CYP2E1 is the principal enzyme responsible for the metabolic conversion of these drugs to their active hepatotoxic metabolites. In particular, CYP2E1 is the rate-limiting enzyme that initiates the cascade of events leading to activation of acetaminophen to the hepatotoxic metabolite, $\mathrm{N}$-acetyl-p- 
benzoquinoneimine and to increase of acetaminophen hepatotoxicity [52]. In the absence of this isozyme, acetaminophen toxicity will only be apparent at high concentrations $[5,30]$. Hepatotoxicity is described in depth, as it is the most frequent clinical observation after acetaminophen-intoxication. In this context, covalent protein binding and oxidative stress are two important initial events highlighted [53]. 3'-Hydroxyacetanilide - non-toxic regioisomer of the analgesic acetaminophen - covalently binds to CYP2E1 with preferential loss of its activity. CYP2E1 enzyme activity (p-nitrophenolhydroxylation) was decreased by $79 \%$ in the mice treated with $3^{\prime}$-hydroxyacetanilide $(600 \mathrm{mg} / \mathrm{kg})[54]$. Coadministration of acetaminophen with inhibitors of CYP2E1 prevented the development of acetaminophen-induced hepatotoxicity in rats. This calls for research for enzyme inhibitors that may be of therapeutic value [52].

CYP2E1-mediated oxidation of halothane to a reactive intermediate trifluoroacyl chloride that covalently binds to hepatic proteins forming trifluoroacetylated neoantigens is believed to be the initiating event in a complex immunologic cascade culminating in antibody formation and severe hepatic necrosis («halothane hepatitis») in susceptible patients. Trifluoroacyl chloride may also hydrolyze to the stable metabolite trifluoroacetic acid. CYP2E1 inactivation by disulfiram inhibits human halothane oxidation to trifluoroacetic acid in vitro and in vivo. Disulfiram inhibition of CYP2E1-mediated halothane oxidation appears to prevent hepatic proteins trifluoroacetylation in vivo [55].

Heavy consumption of alcohol, which results in CYP2E1 induction, increases individual susceptibility to toxic or carcinogenic effects of some drugs [51]. Chronic alcohol consumption may potentiate acetaminophen hepatotoxicity through enhanced formation of $\mathrm{N}$-acetyl-p-benzoquinoneimine via induction of CYP2E1. However, CYP2E1 induction appears to be insufficient to explain the claimed magnitude of the interaction. CYP2E1 plays an important role in selective depletion of liver mitochondrial glutathione (GSH) by chronic ethanol [56]. Contrasting with the stimulating effects of chronic consumption, acute ethanol intake inhibits the metabolism of some drugs. CYP2E1 also activates some other commonly used drugs to their toxic metabolites, and promotes carcinogenesis [27].

CYP2E1-mediated reactions of reduction. CYP$2 \mathrm{E} 1$ is effectively involved in reactions of reduction, in particular, carbon tetrachloride $\left(\mathrm{CCl}_{4}\right)$-induced hepatotoxicity is one good example. $\mathrm{CCl}_{4}$ is activated by CYP2E1 to form the trichloromethyl radical $\mathrm{CCl}_{3}$. It was found that elevated cytotoxicity of carbon tetrachloride plays an important role in the oxidative stress, induced by CYP2E1 [57]. Cytotoxic frec radicals generated during the metabolism of carbon tetrachloride by CYP2E1 are thought to cause hepatotoxicity. Hsp70 mRNA level, a potential marker of oxidative stress, is significantly increased after carbon tetrachloride treatment. These results suggest that the oxidative stress induced by CYP2E1 plays an important role in the increase of carbon tetrachloride cytotoxicity in CYP2E1-overexpressing cells [57]. In addition, a dramatic decrease in CYP2E1-catalyzed p-nitrophenol activity and complete loss of immunoreactive CYP2E1 were observed in mice after $\mathrm{CCl}_{4}$ treatment, suggesting that CYP2E1 was degraded during the process of carbon tetrachloride-induced hepatotoxicity [58].

In monolayer cultures of rat primary hepatocytes covalent binding of ${ }^{14} \mathrm{C}$-labeled metabolites of carbon tetrachloride was detected immediately after exposure to $\mathrm{CCl}_{4}$. This radical can bind to cellular molecules (nucleic acid, protein, lipid), impairing crucial cellular processes such as lipid metabolism. The experiments confirm that covalent binding of the $\mathrm{CCl}_{3}$ radical to cell components initiates inhibition of lipoprotein secretion and thus steatosis, whereas reaction with oxygen, to form $\mathrm{CCl}_{3}-\mathrm{OO}^{*}$, initiates lipid peroxidation. These two processes are independent of each other, and the extent to which either process develops depends on partial oxygen pressure. The former process may result in adduct formation and, ultimately, cancer initiation, whereas the latter results in loss of calcium homeostasis, apoptosis and cell death $[59]$.

$\mathrm{CCl}_{4}$ continues to provide an important service today as a model substance to elucidate the mechanisms of hepatotoxic effects such as fatty degeneration, fibrosis, hepatocellular death, and carcinogenicity. Adduct formation between $\mathrm{CCl}_{3}$ and DNA is thought to function as initiator of hepatic cancer. At the molecular level $\mathrm{CCl}_{4}$ activates tumour necrosis factor (TNF) $\alpha$, nitric oxide (NO), and transforming growth factors (TGF) $-\alpha$ and $-\beta$ in the cell, processes that appear to direct the cell primarily toward (self-) destruction or fibrosis [60].

CYP2E1 role in reactive oxygen radical generation. It is known, that CYP2E1 exhibits an 
enhanced NADPH oxidase activity (NADPH oxidation is uncoupled from substrate hydroxylation) as it appears to be poorly coupled with NADPH-cytochrome $\mathrm{P} 450$ reductase [61]. CYP2E1 possesses a unique capacity to reduce molecular oxygen to highly reactive compounds - superoxide anion radical, single oxygen, hydrogen peroxide $[7,62]$. In the presence of certain iron complexes, CYP2E1 produces powerful oxidants such as hydroxyl radicals [40, 61]. It is known that due to steady-state in spin state cytochrome P450 may bind molecular oxygen and passage into high spin state only after binding the substrate. As compared to other cytochromes CYP2E1 generates reactive oxygen species (ROS) even in the absence of substrate. Reactive oxyradicals might initiate membranous lipid peroxidation [63]. Increased rates of lipid peroxidation result in yielding products, mainly aldehydes, which activate immune cells for cytokine production and Ito cells for collagen formation. CYP2E1 mediated formation of reactive lipid peroxidation products and $\alpha$-hydroxyethyl radicals gives rise to protein adduct formation, some of which can cause autoimmune reactions [7]. This way of reactive oxygen species production has certain advantages. In particular, degradation of the endoplasmic reticulum and other cell compartments in the presence of free radicals may constitute a physiological mechanism of adaptation to changes in the environment.

Metabolism of endogenous compounds by CYP2E1. Ethanol-inducible CYP2E1 also plays a significant role in the metabolism of endogenous compounds including fatty acids, ketone bodies and some cytotoxins $[38,62,64]$. CYP2E1 is involved in acetone catabolism and the cascade of events connected with converting acetone to acetol and then to methylglyoxal, both intermediates in the gluconeogenic pathway. This was revealed through experiments in vitro and in vivo [65]. CYP2E1 assumes a more important role under conditions of increased blood acetone levels, in particular after chronic consumption of ethanol, and under states, which accompany hyperketonemy and ketoacidosis. Glucose formation from acetone may also contribute to the maintenance of a constant blood glucose level, but it seems to be only a minor source for that. Acetonemiae of endogenous origin are due to the increased rate of acetone production followed by an increase of degrading capacity as CYP2E1 becomes induced. Exogenous acetonemiae usually result from intoxications caused by either acetone itself or other exogenous compounds [64]. CYP2E1 also plays an important role in $\omega$ - and $(\omega-1)$-hydroxylation of lauric and arachidonic acids $[47,66]$. Hydroxylation of arachidonic acids results in the synthesis of some hydroxyeicosatetraenoic acids, which have physiological and pharmacological importance [5]. CYP2E1 substrates also include fatty acid hydrogen peroxides. Their oxidation leads to formation of aldehydes and alkanes [67].

On the other side, it is demonstrated that animals deficient in expression of the enzyme were fertile, developed normally, and exhibited no obvious phenotypic abnormalities, thus indicating that CYP2El has no critical role in mammalian development and physiology in the absence of external stimuli [5].

Markers for CYP2E1 activity. Enzymatic activities are routinely used to identify the contribution of individual forms of cytochrome P450 to a particular biotransformation. p-Nitrophenol O-hydroxylation has been widely used as a probe for measure of microsomal CYP2E1 catalytic activity $[68,69]$. Substrate markers of CYP2E1 catalytic activity are also aniline, although it is not specific for CYP2E1 [7, $70]$, chlorzoxazone $[15,17,71-73]$ and $\mathrm{N}$-nitrosodimethylamine $[24,74]$. Carbon tetrachloride-dependent lipid peroxidation displays best correlation with CYP2E1 expression under all conditions $[7,57,60]$. In addition, trimethadione metabolism is a good CYP2E1 probe for liver disease in vivo and in vitro [17]. Chlorzoxazone was found to be oxidized only to 6-hydroxychlorzoxazone in human liver microsomes. Results of steady-state kinetics are consistent with the view that only a single enzyme catalyzes the reaction. Rates of chlorzoxazone 6-hydroxylation in different human liver microsomal preparations were well correlated with levels of immunochemically measured CYP2E1 and rates of $\mathrm{N}$-nitrosodimethylamine oxidation [71]. In vivo chlorzoxazone 6-hydroxylation may have potential use as a non-invasive and selective test in estimating the expression and activity of human CYP2E1 and its significance as a risk factor in the toxicity and carcinogenicity of a number of solvents, nitrosamines, and drugs. Preliminary data on humans exposed to organic solvents indicates that chlorzoxazone metabolism may be a biomarker of occupational exposure to organic solvents [31].

Inter-individual variance of CXP2EI activity in humans. Differences in biotransformation activities may alter the bioavailability or efficacy of drugs, provide protection from certain xenobiotic and envi- 
ronmental agents, or increase toxicity of others [75]. Significant inter-individual variability was established in expression gene, in the levels of CYP2EI mRNA, protein and functional activity in human hepatic microsomes [75]. CYP2E1 protein content variation in individual human liver microsomes was $12[75]$ to $50[7,61,76]$ times. Important inter-individual variability in the expression of CYP2EI was observed and more than 30-fold differences in hepatic levels are reported [61, 77]. Rates of chlorzoxazone 6hydroxylation also vary considerably among human liver samples [71].

Cytochrome P450 enzymes are responsible for the majority of oxidations of drugs and other xenobiotics, and differences in their expression may directly produce inter-individual differences in susceptibility to compounds whose toxicity is modulated by these enzymes [75]. Analysis of variability in the levels of CYP2E1 mRNA, protein and functional activity in a human liver revealed that variation in CYP2E1 mRNA (18-fold) was greater than the variation seen in CYP2E1 protein (2-fold) and functional activity (4-fold) determined using two probe substrates, chlorzoxazone and p-nitrophenol. Although protein and functional activity showed a significant correlation $(r=0.93$ and $r=0.83$ for chlorzoxazone and p-nitrophenol, respectively), there was no correlation between any of these parameters and mRNA levels [78]. The rates of product formation and the ratios of denitrosation to dealkylation varied with the structures and concentrations of the substrates as well as with the microsomal samples tested [44].

Inter-individual variability in CYP2E1 activity as measured in vivo in healthy subjects appears to be considerably less than that expected based on in vitro studies. Whether such variability is associated with individual susceptibility to CYP2E1-mediated toxicity remains to be determined [79]. The molecular mechanisms underlying inter-individual variability of CYP2E1 content and its catalytic activity are not established yet. Two major hypotheses were proposed for understanding this inter-individual variability - it may be of genetic origin or reflect the influence of environmental factors.

Variability in expression gene, in the levels of CYP2E1 mRNA, protein and functional activity CYP2E1 may result from genomic polymorphisms. In accordance with this hypothesis, differences in the regulatory region of CYP2E1 are partially responsible for the in vivo intersubject variation in CYP2E1 activity. The presence of the insertion mutation is associated with greater CYP2E1 metabolic ability, but only among individuals who either were obese or had recently consumed ethanol [80]. However, in another study the relationship between genotype and phenotypic catalytic activity of the enzyme has not been defined. The effects of specific dietary factors, other than ethanol, which have been shown in animal and in vitro studies to modulate CYP2E1 activity, are unknown in humans $[79,81]$. No relationships were found between measures of CYP2EI activity, both in vivo and in vitro, and genomic polymorphisms in CYP2E1 gene identified by $R$ sal/Pstl and Dral restriction fragment length polymorphisms [82 ]. According to the second hypothesis, intersubject variation in CYP2E1 gene expression may be the consequence of complicated gene-environment interactions and reflect their influence. Available studies indicate a wide variation in human CYP2E1 expression, which are very likely based on complex gene-environment interactions. Major inter-ethnic differences are apparent on the genotyping and phenotyping levels [73].

More probably, the predominant reason consists in different degrees of CYP2E1 induction by substrates-xenobiotics. Exogenous inducers elevate CYP2EI protein levels through both increased translational efficiency and stabilization of the protein from degradation, which appears to occur primarily through ubiquitination and proteasomal degradation. CYP2E1 mRNA and protein levels are altered in response to multiple stimuli - genetic factors, age, weight, diet, and sex.

Ethnic differences in CYP2E1 expression. The importance of the human isoform CYP2EI for occupational and environmental medicine is derived from its unique substrate spectrum that includes a number of important high-production chemicals, such as aliphatic and aromatic hydrocarbons, solvents and industrial monomers (i. e. alkanes, alkenes, aromatic and halogenated hydrocarbons) [73].

Possible consequences of differential inter-individual and inter-ethnic susceptibilities to harmful xenobiotic effects are related to individual expressions of clinical symptoms of chemical toxicity, to results of biological monitoring of exposed workers, and to the interpretation of results of epidemiological or molecular-epidemiological studies.

There are consistent ethnic differences in CYP2E1 enzyme expression, mostly demonstrated between European and Japanese populations, which 
point to a major impact of genetic factors [73]. The most frequently studied genetic polymorphisms are the restriction fragment length polymorphisms PstI/Rsal (mutant allele: CYP2E1*5B) located in the $5^{\prime}$-flanking region of the gene, as well as the DraI polymorphism (mutant allele: CYP2E1*6) located in intron 6 . These polymorphisms are partly related, as they form the common allele designated CYP2E1*5A [73].

The chlorzoxazone plasma concentrations after oral administration were significantly higher and its elimination rate slower in Japanese compared to Caucasian men. This was confirmed by in vitro studies with microsomes prepared from livers of individuals representative of two racial groups. CYP$2 \mathrm{E} 1$ levels were lower $(61 \%, \mathrm{P}<0.002)$ and CYP2E1-mediated chlorzoxazone 6-hydroxylase (22\%, $\mathrm{P}<0.001)$ and aniline 4-hydroxylase $(35 \%, \mathrm{P}<$ $<0.0001$ ) activities were reduced in Japanese preparations compared to those from Caucasians [82]. Also, similarity in the metabolism of chlorzoxazone between Mexicans and European Americans suggests that the risk associated with CYP2E1-mediated activation of procarcinogens is not different between these two populations [83].

Specific inhibitors of CYP2E1. Ethanol-inducible CYP2E1 is responsible for metabolism of many xenobiotics which exert toxic effects in humans. Compounds that inhibit CYP2E1 synthesis and activity are of particular interest, since they could be possibly utilized as preventive drugs to mitigate the harmful influence of unfavorable environmental factors. Specific inhibitors might constitute valuable tools in the elucidation of the pharmacological and toxicological roles of this isozyme in vivo. Selective inhibitors of CYP2E1 synthesis and catalytic activity are chloromethiazole, disulfiram, diallyl sulphide, diallyl sulfoxide and diallyl sulfone, diallyl disulfide and allylmethylsulfide, diethyldithiocarbamate, phenethylisothiocyanate and 3,4- and 3,5-dichlorophenyl derivatives [84-86]. Recent results have shown that human CYP2E1 expression in vivo is almost completely inhibited in control subjects and in alcoholic patients treated with chloromethiazole [84]. Several CYP2E1 inhibitors are of significant therapeutic value. Polyenylphosphatidylcholine (PPC), an innocuous mixture of polyunsaturated phosphatidylcholines extracted from soybeans (and its active component dilinoleoylphosphatidylcholine), were discovered to decrease CYP2E1 activity. PPC also opposes hepa- tic oxidative stress and fibrosis [27 ]. Diallyl sulphide, diallyl sulfoxide and diallyl sulfone have been shown to reduce carbon tetrachloride-, N-nitrosodimethylamine- and acetaminophen-induced toxicity in rodents. All three inhibitors are substrates for CYP2E1. Moreover, these compounds have been shown to reduce the incidence of a multitude of chemically induced tumors in animal models [87]. Disulfiram inhibition of CYP2E1-mediated halothane oxidation prevents hepatic protein trifluoroacetylation [55].

Chloromethiazole is an efficient transcriptional inhibitor of expression of rat hepatic ethanol-inducible CYP2E1. Previously obtained data indicate that CYP2E1 gene is transcriptionally activated in response to medium change and that chloromethiazole, apart from being a transcriptional inhibitor of CYP2E1 expression, acts in addition as an efficient high-affinity post-translational inhibitor of CYP2E1, probably due to allosteric destabilization of the enzyme [84]. 4-Fold induction of CYP2E1 was observed after 3 days of starvation, accompanied by a similar increase in the level of the corresponding mRNA. Chloromethiazole specifically inhibited the elevation of CYP2E1 mRNA and protein [88]. In conclusion, it can be suggested that chloromethiazole might constitute an efficient and specific inhibitor of CYP2E1 expression suitable for in vivo experiments.

Also, 3'-hydroxyacetanilide has been previously studied as a nontoxic regioisomer of acetaminophen that covalently binds to CYP2E 1 and strongly inhibits it with preferential loss of activity [54 ]. Inflammatory cytokines inhibit CYP2E1 expression by multiple mechanisms, including control of hepatocyte nuclear factor (HNF) $-1 \alpha$ function and regulation of other transcriptional factors acting on the CYP2E1 $5^{\prime}$ upstream regulatory region. Interestingly, IL- $1 \beta$, but not TNF $\alpha$, was found to reduce $\mathrm{HNF}-1 \alpha$ binding to the CYP2E1 promoter. In addition, regulation of factors of importance for the CYP2E1 mRNA stability may be involved [89].

Currently, constant search for new CYP2E1 inhibitors is performed. For example, 3,4- and 3,5dichlorophenyl derivatives may be useful as potent CYP2E1 inhibitors [85]. CYP2E1 is one of the major cytochrome $\mathrm{P} 450$ forms whose expression is strongly inhibited by inflammatory cytokines in humans and rodents. All three cytokines - IL- $1 \beta$, TNF $\alpha$, or IL-6 decreased the CYP2E1 mRNA levels in Fao rat hepatoma cell líne after $24 \mathrm{~h}$. In contrast, significant inhibition of CYP2E1 protein was seen only after 72 
$h$ [54]. The effects of antifungals: bifonazole, econazole, clotrimazole, ketoconazole, miconazole; CNSactive drugs: chlorpromazine, desipramine, fluphenazine, thioridazine; were investigated on the enzyme activities selective for CYP2E1. None of the drugs could be considered as a potent inhibitor of CYP2E1 [68].

Mechanisms of CYP2El induction. It is known that monooxygenase cytochrome P450-dependent system adapts to environmental changes easily due to isozymes induction by substrates. Understanding the mechanisms of isozyme induction is important for prediction of cytotoxic, mutagenic or carcinogenic action of many chemicals. Specific inductors of CYP2E1 activity are as follows: ethanol, imidazole, dimethylsulphoxide, 2-propanol, pyridine, isoniazid, acetone, pyrazine, and pyrazole. Substrates-inductors of CYP2E1 are ethanol and acetone.

On the contrary, imidazole induces CYP2E1, but is not its substrate: Acetaminophen, carbon tetrachloride, chlorzoxazone are CYP2E1 substrates but not inductors [7]. CYP2E1 induction by specific substrates has important physiological significance for the efficient elimination of foreign chemicals from the body. The induction of CYP2E1 protein expression by low-molecular compounds was demonstrated in vitro and in vivo. CYP2E1 expression increases in rat liver through administration of ethanol, acetone, pyrazole, and other related small molecular weight compounds. Administration of ethanol, dimethylsulphoxide, 2propanol or imidazole to rats caused 2-7-fold increases in the level of hepatic ethanol-inducible cytochrome P450 (P450j), without any concomitant enhancement of corresponding mRNA. All the compounds were capable of stabilizing epnzyme in hepatocyte cultures for at least three days, whereas mRNA rapidly disappeared $[90,91]$. This induction is not the result of an increase in CYP2E1 mRNA, but could be due to either an increase in translation rate or a decrease in protein degradation. Immunoreactive CYP2E1 protein level and activity were significantly induced by isoniazid. At the same time two structural analogues of isoniazid - isonicotinamide and isonicotinic acid - were also tested and found to have a markedly decreased ability to induce CYP2E1 [70].

No changes were detected in hepatic CYP2El mRNA levels at any time after acetone treatment, whereas rapid rises were observed in the microsomal amount of CYP2E1 protein and CYP2E1-catalyzed 4-nitrophenol hydroxylase, and carbon-tetrachlorideinitiated lipid-peroxidation activities. However, CYP2E1-dependent catalytic activities declined much faster than the immunodetectable CYP2E1 protein, suggesting that this isozyme is inactivated prior to degradation. Similar results were seen in primary hepatocyte cultures [28 ]. Treatment of primary cultured rat hepatocytes with CYP2E1 inducers, i. e. ethanol, acetone, and pyrazine for $24 \mathrm{~h}$, resulted in 2-8-fold increases in CYP2E1 protein levels. Pyridine addition to primary rat hepatocytes resulted in a 3.5-fold enhancement in CYP2E1 protein expression in the absence of any pyridine-mediated increase in mRNA expression [92]. A single injection of pyridine (100 mg/kg, i. p.) increased CYP2E1 levels 2-, 3and 4-fold after 6,10 and $24 \mathrm{~h}$, respectively, relative to controls. Induction of CYP2E1 was dose-dependent over the range 10 to $200 \mathrm{mg} / \mathrm{kg}$. Hybridization analysis failed to reveal an increase in CYP2E1 mRNA in either total RNA or poly (A+) mRNA following pyridine treatment. Cycloheximide administration prevented the induction of CYP2E1 by pyridine completely, whereas actinomycin $D$ had no appreciable effect. These results suggest that induction of CYP2E1 at early times following acute pyridine exposure involves protein synthesis possibly through increased translational efficiency [93].

A question of particular interest is the exact localization (liver region) of CYP2E1 expression induction. Chronic ethanol exposure causes marked induction of the ethanol-inducible CYP2E1 in the centrilobular liver region. Analysis of cell lysates isolated from the periportal and perivenous region revealed that the increase in CYP2E1 mRNA by fasting occurred in the perivenous region [88]. CYP. $2 \mathrm{El}$ synthesis rate and catalytic activity are induced under a variety of physiological and pathophysiological conditions such as fasting, diabetes, obesity, high fat diet, non alcohol induced steatohepatitis and also some environmental factors $[16,92,94,95]$. Levels of CYP2E1 are elevated after acute and chronic alcohol treatment [40]. Diabetes has been reported to increase the expression of CYP2E1 mRNA and protein several-fold, and enhanced expression has been associated with elevated ketone bodies [96 ]. Adverse hepatic events associated with type II diabetes may be in part a result of enhanced CYP2E1 expression and activity [97].

CYP2E1 is reported to be induced by ketosis. The enzyme activities (aniline hydroxylase) in hepa- 
tic microsomes were elevated about 2-3-fold by feeding rats with a high fat diet for 3 days. The increases in enzyme activities were also accompanied by 3-fold increases in immunoreactive CYP2E1 protein and its mRNA. Higher levels of CYP2E1 mRNA correlated positively $(r=0.73)$ with plasma concentrations of acetoacetate and $\beta$-hydroxybutyrate. These data indicate that CYP2E1 induction during the ketosis caused by high fat feeding appears to be due to pretranslational activation and that is similar to the induction mechanism in fasted and diabetic animals [98].

It was observed that induction of CYP2E1 by many low-molecular-weight compounds elevates CYP$2 \mathrm{E} 1$ content and activity. The increase in CYP2E1 protein expression was not accompanied by any significant increase in mRNA expression [99]. The induction of CYP2E1 by isoniazid was also not accompanied by an increased level of CYP2E1 mRNA, and was completely blocked by pretreatment with cycloheximide or sodium fluoride, inhibitors of mRNA translation. These data thus suggest that CYP2E1 induction by isoniazid is due to activation of CYP2E1 mRNA translation and that the hydrazide group on the pyridine ring of isoniazid is important both in the selective induction of CYP2E1 and for magnitude of effect [70].

Thus, xenobiotic inducers elevate CYP2E1 protein levels without any concomitant enhancement of corresponding mRNA. Mechanisms of CYP2E1 induction by ethanol, imidazole, dimethylsulphoxide, 2propanol, pyridine, isoniazid, acetone, pyrazine, and pyrazole may be mediated either through elevated mRNA translational efficiency due to higher protein translation rate or mRNA stabilization - or protein stabilization from degradation [38, 90, 91$]$. Altered expression of hepatic CYP2E1 by xenobiotic or physiological stimuli is largely mediated through posttranscriptional mechanisms that may include altered CYP2E1 mRNA translation and/or protein degradation. Approximately $30-40 \%$ of CYP2E1 mRNA was not associated with polysomes and therefore not actively engaged in protein synthesis. It is probable that secondary structure in the $5^{\prime}$ UTR of CYP2E1 mRNA is at least partially responsible for the inefficient translation of this mRNA [100].

Regulation of CYP2E1 expression and activity. Many toxic compounds are activated by CYP2E1 to reactive metabolites representing a potential hazard for cellular homeostasis. Therefore, knowledge about
CYP2E1 regulation could be of great biological importance. Several publications were devoted to elucidation of mechanism of CYP2E1 expression and activity regulation. The regulation of the steady-state CYP2E1 expression and content is an extremely complex process and is exerted at several different cellular levels [7]. The enzyme is regulated by transcriptional activation, mRNA stabilization, increased mRNA translation and a posttranslational mechanism which involves enzyme stabilization and decreased protein degradation [7, 38 ]. The principal mechanism, which controls the induction process, depends on the chemical nature of the inducer, the age, and the nutritional and hormonal status of the human subject. Moreover, it is thought that environmental factors induce protein in different tissues with varying strength resulting in considerable inter-individual variation in protein level.

The expression of CYP2E1 was found to be developmentally regulated. No immunodetectable protein or CYP2E1 mRNA was present in newborn rats. For example, the rat hepatic CYP2E1 gene becomes transcriptionally activated and the dramatic increase in mRNA level occurs within $24 \mathrm{~h}$ after birth [101 ]. Rapid increases in CYP2E1 mRNA and protein occurred within 1 week after birth in both male and female rats [6]. mRNA level increased 3-fold from 2 to 6 days of age and remained elevated up to the age of 3 months in both sexes [2]. The increases in both CYP2E1 and its mRNA paralleled the change in aniline hydroxylase activity during development. Run-on transcriptional analysis confirmed that these increases were due to transcriptional activation of CYP2E1 gene [6]. It is suggested that CYP2E1 gene is positively regulated in adult rats by $\mathrm{HNF}-1 \alpha$ or a protein similar in DNA-binding properties to HNF1a. To date the role of this factor or other proteinprotein interactions in the lack of CYP2E1 transcription in fetal and newborn animals remains unclear [101].

One major mode of CYP2E1 regulation is at the posttranscriptional level, since many low-molecularwcight compounds stabilize the enzyme against proteolysis by the proteasome complex. In an in vitro system containing human liver microsomes, degradation of CYP2E1 in the microsomes requires addition of the human liver cytosol fraction in a reaction sensitive to inhibitors of the proteasome complex. It is not clear how CYP2E1 in the microsomal membrane becomes accessible to the cytosolic proteasome. 
Since molecular chaperones play an essential role in protein folding and degradation, the possible role of heat shock proteins in CYP2E 1 degradation by this reconstituted system was also evaluated [102]. CYP$2 \mathrm{E} 1$ is regulated by the chaperone machinery and can be ubiquitylated by the hsp70-dependent E3 ubiquitin ligase CHIP. A general model was elaborated of how substrates, such as ethanol, can regulate the interaction of CYP2E1 with the chaperones hsp90 and hsp70 to alter enzyme turnover profoundly [103].

In conclusion, several different modes of CYP2E1 regulation exist. In particular, elevated mRNA levels (10-fold) in subjects with diabetes and after fasting are due to mRNA stabilization and increase in gene transcription, respectively. In contrast to transcriptional activation during development, stabilization of CYP2E1 by many exogenous low-molecular-weight substrates, such as ethanol and acetone, might be due to posttranscriptional events, appears to be a common mechanism by which CYP2E1 is regulated [6]. It can be concluded that CYP2E1 is mainly regulated at a posttranscriptional level.

Regulation of CYP2E1 activity by hormones. CYP2EI mRNA and protein levels are altered in response to pathophysiological conditions initiated by hormones including insulin, glucagon, growth hormone, leptin and growth factors such as epidermal growth factor and hepatocyte growth factor, thus providing evidence that CYP2E1 expression is under tight homeostatic control [38].

Regulation of CYP2E1 by hormones occurs on transcriptional level since variation in protein concentration correlates with mRNA level $[38,96]$. Considerable intensification (7-fold) of mRNA synthesis and protein content by glucagons was observed in primary cultured rat hepatocytes [96 ]. In contrast, insulin and growth hormone decrease mRNA synthesis and content significantly $[96,104]$. It was demonstrated on primary cultured rat hepatocytes that decreasing the insulin level in the culture medium enhanced xenobiotic-mediated CYP2E1 expression [92]. Insulin produced a concentration-dependent decrease in CYP2E1 mRNA levels and CYP2E1 mRNA half-life decreased from approximately 48 hours in the absence of insulin to approximately 15 hours at 10 nmol/1 insulin. Inhibitor wortmannin ameliorated the insulin-mediated decrease in CYP2E1 mRNA levels [96]. The relative roles of pituitary hormones (especially growth hormone) and testicular hormones (especially testosterone) in the regulation of hepatic
CYP2E1 were studied in the male rats. Depletion of pituitary hormones by hypophysectomy resulted in 6-fold increases in CYP2E1 in the liver with a concomitant increase in CYP2E1 mRNA [105]. Grom wh hormone may also lead to decrease in mRNA levels. Available evidence suggests that the induction of hepatic CYP2E1 by hypophysectomy may result from reduced glucose utilization, and that the effect of growth hormone on CYP2E1 expression may be mediated with enhanced glucose utilization, but not with insulin production [104]. Thus, CYP2E1 regulation occurs on transcriptional level under a variety of physiological and pathophysiological conditions such as fasting, diabetes, obesity, and non alcoholinduced steatohepatitis. All these states are accompanied by several-fold increase in CYP2E1 mRNA and protein expression, which has been associated with elevated ketone bodies. The data obtained provide evidence on involvement of transcriptional and posttranscriptional mechanisms in the hormone-mediated regulation of CYP2E1.

CYP2E1 role in ethanol metabolism. CYP2E1 plays an important role in ethanol metabolism. Oxidation of ethanol via alcohol dehydrogenase (ADH) explains various metabolic effects of ethanol but does not account for the tolerance. In case of chronic alcohol consumption, the existence of an additional pathway was suggested and then described by Lieber and DeCarli - namely, the microsomal ethanol oxidizing system (MEOS), involving cytochrome P450. After chronic ethanol consumption, the activity of the MEOS increases considerably, that is associated with increase in the content of cytochrome P450, especially CYP2E1, although other P450s - CYP1A2 and CYP3A4 - are involved [27]. However, the mean level of CYP2E1-dependent ethanol oxidation in human liver microsomes was twice that of CYPIA2 and CYP3A4. Alcohol and xenobiotics share the same oxidative microsomal pathway, which is mainly located in the endoplasmic reticulum of hepatocytes. MEOS is responsible for approximately $10-15 \%$ of ethanol metabolism.

CYP2E1 is the key enzyme of the microsomal pathway of ethanol oxidation. The correlation of MEOS activity with the levels of immunoreactive CYP2E1 in individual human microsomes was highly significant $(r 2=0.88, \mathrm{P}<0.01) \quad[106]$ ]. 7 -fold induction of CYP2E1 by ethanol was demonstrated in vivo [107], while 2-fold induction was observed in Fao rat hepatoma cells [84]. CYP2E1 is inducible by chronic 
ethanol consumption and its activity increases 3 to 5-fold in liver samples from alcoholics [51]. Acetaldehyde as well as ethanol is metabolized by CYP2E1 in the presence of NADPH. The microsomal acetaldehyde-oxidizing system activity was increased 2.3-fold by giving rats ethanol [106]. Induction of CYP2E1 by ethanol is one of the central pathways by which ethanol generates a state of oxidative stress in hepatocytes [63]. Heavy consumption of alcohol, which results in CYP2E1 induction, increases individual susceptibility to the toxic or carcinogenic effects of various xenobiotics, in particular drugs [51 ]. CYP2EL induction by ethanol may accelerate the carcinogenic action of $\mathrm{N}$-nitrosodimethylamine at very low concentrations. Both in vitro and in vivo results indicate that elevated CYP2E1 level enhances cisplatin-induced hepatotoxicity, and the mechanism may involve increased production of ROS and oxidative stress [108].

Induction of CYP2E1 in the human liver by ethanol. Whereas long-term ethanol consumption elicits a marked increase in hepatic CYP2E1 content, the molecular mechanism by which ethanol produces this effect is the subject of controversy in animals, and it has not been elucidated in human beings. Debate still exists as to the precise mechanism of CYP2E1 induction by ethanol. Possible mechanisms have been proposed, ranging from enhanced de novo enzyme synthesis caused by elevated CYP2E1 mRNA levels, enhanced translation of preexisting mRNA or stabilization of CYP2E1 protein. Thus, two hypotheses exist on mechanism of CYP2E1 induction by ethanol - it may be a result of increasing protein synthesis [107] or consequence of CYP2E1 stabilization by ethanol [90]. To evaluate these mechanisms, the time course of hepatic CYP2E1 protein induction was examined in rats. Animals were pairfed liquid diets containing $36 \%$ of total calories as either ethanol or dextrin-maltose (controls) for 28 days. It was shown that induction of hepatic CYP2E1 protein by ethanol in vivo involves increased enzyme synthesis rather than decreased enzyme degradation. This enhancement of de novo CYP2E1 synthesis most likely entails the ethanol-mediated increase of steadystate levels of CYP2E1 mRNA and/or the stimulation of its translational efficiency [107].

Other authors suggest that CYP2E1 protein stabilization is responsible for protein induction by ethanol $[90,109]$. Results of experiments with chronic ethanol intake reveal that induction of CYP2E1 during chronic ethanol exposure in rats occurs by a complex two step mechanism $[109,110]$. The first step of induction is associated with relatively low blood alcohol concentrations $(<200 \mathrm{mg} / \mathrm{dl})$, and involves increases in CYP2E1-dependent activities and apoprotein levels with no increases in steady-state mRNA encoding CYP2E1 and appears to be posttranscriptional. The second step of this process occurs at higher blood alcohol concentrations (>300 mg/dl) and involves elevated mRNA levels. It is demonstrated that CYP2EI induction by chronic ethanol is associated with increased CYP2E1 gene transcription [109]. At low blood alcohol concentrations a 6- to 7-fold induction was accompanied by a 4 - to 5-fold increase in CYP2E1 apoprotein, but no increase in CYP2E I mRNA levels. In contrast, at higher blood alcohol concentrations, induction of p-nitrophenol hydroxylase was 15- to 16-fold, induction of CYP2E1 apoprotein was 12- to 13-fold and CYP2E1 mRNA was elevated 5- to 6-fold [110]. It indicates that transcriptional activation of CYP2E1 requires the long-term presence of highly intoxicating ethanol levels. The mechanisms underlying these induction steps still require intense investigation.

Mechanisms of CYP2E1 degradation. CYP2E1 is distinguished from other cytochrome P450 enzymes by its rapid intracellular turnover. Alcohol-inducible CYP2El has the most rapid turnover of any member of this large superfamily of membrane-bound oxygenases, and its degradation rate is altered profoundly by various substrates [103].

In the absence of substrate, CYP2E1 is degraded with a biphasic half-life of about $6-7 \mathrm{~h}$, followed by a slower secondary phase of about $37 \mathrm{~h}$ [91]. In accordance with recently obtained results, CYP2E1 half-life in the absence of substrate in vivo varied from $4-7 \mathrm{~h}[62,111]$ to $9 \mathrm{~h}[112]$. Factors, which regulate rapid turnover of CYP2E1 or initiate its rapid degradation, are unknown. Several mechanisms for the rapid degradation have been postulated. Interesting hypothesis is proposed on the basis of inherent CYP2E1 properties [62]. It is known that CYP2E1 has a high degree of oxydase activity in the absence of substrate, resulting in production of reactive oxygen radicals. Therefore, rapid intracellular turnover of the enzyme may be partly due to covalent modifications by such radicals. NADPH-dependent generation of reactive oxygen radicals may evoke oxidative modification of CYP2E1 and labilization, and subsequent rapid enzyme degradation. Inactiva- 
tion of CYP2E1 may play a role in regulating the levels of enzyme and thereby minimize direct toxicity of excessive production of CYP2E1-derived ROS. Perhaps, other changes occur during catalytic cycling, in which case the inhibition of electron supply from NADPH-cytochrome $P 450$ reductase would be expected to stabilize the protein. These results demonstrate that short half-life of CYP2E1 in vivo may be largely due to the rapid destabilization of the enzyme during catalytic cycling rather than to the intrinsic instability of the protein molecule.

In the absence of substrate, CYP2E1 undergoes rapid degradation, which is necessary for apoprotein phosphorylation on serine-129. In this case, enzyme inactivation is followed by proteolytic degradation [113]. Phosphorylation serine-129 causes loss heme in vitro and an enhanced rate of P450IIEl degradation enzyme in hepatyocytes [91 ]. By site-directed mutations of the cDNA coding for CYP2E1, Ser129 was replaced by alanine (Ala) or glycine (Gly). These findings argue that involvement of Ser129 and its phosphorylation is not in determining CYP2E1 protein level, but rather in controlling its catalytic activity [114]. cAMP-dependent phosphorylation of CYP2E1 is followed by degradation by serine proteases present in the endoplasmic reticulum [62]. Two serine proteinases capable of digesting CYP2E1 have been purified from sodium cholate solubilized rat liver microsomal membranes which indicate that the proteinases can degrade CYP2E1 in its native environment [115]. It is suggested that these proteinases play a role in the rapid phase of cytochrome $\mathbf{P 4 5 0}$ degradation in the endoplasmic reticulum. Subfractionation of microsomes revealed that the $\mathrm{Mg}(2+)$ ATP-dependent proteolytic system active on CYP2E1 was present in both rough and smooth endoplasmic reticulurn [112].

The mechanism underlying the rapid degradation of CYP2E1 also appears to involve the ubiquitinproteasome proteolytic pathway $[102,111,116]$. Mechanism-based inactivation of liver microsomal enzyme in vivo and/or in vitro, via heme modification of the protein, results in accelerated proteolytic degradation of the enzyme that is preceded by the ubiquitination of the protein, thereby implicating the ubiquitin-ATP-dependent $26 S$ proteasomal system [116].

The proteasome complex constitutes a major extra lysosomal proteolytic system which is responsible for ubiquitin-dependent pathway of intra- cellular proteolysis. The recent studies revealed the involvement of the proteasomes in degradation of membranous endoplasmic reticulum proteins [117]. Using the cytosolic fraction, the formation of high M(r) ubiquitin-CYP2E1 conjugates was observed in vitro [111]. On the contrary, even in the presence of proteasome inhibitors high molecular weight ubiquitin conjugates were not observed. Mutagenesis of two putative ubiquitination sites (Lys317 and 324) did not alter the degradation of CYP2E1 [118].

Using PS-341, a potent proteasome inhibitor in vivo, it was demonstrated that CYP2E1 induced by ethanol is degraded by the proteasonie [119]. Molecular modelling of a predicted cytosolic domain of CYP2E1 resulted in identification of a putative ubiquitination-target/substrate-interaction structure (residues $317-340$ ). An affinity-purified antibody reactive to this domain quenched CYP2E1 ubiquitination in a concentration-dependent manner in a rabbit reticulocyte lysate-based ubiquitination assay. These two observations suggest an association between the CYP2E1 cytosolic domain involved in catalysis and its serving as a target for ubiquitination. Thus, these results provide a plausible mechanistic explanation for the observation that substrate binding shields CYP2E1 protein from turnover by the ubiquitin-proteasome-dependent machinery [15]. However, the mechanism of CYP2E1 degradation by ubiquitinproteasome proteolytic pathway has not been revealed completely. Several studies have shown the involvement of molecular chaperones in protein degradation [120]. The sensitivity to geldanamycin and molybdate and the immunodepletion experiments suggest that hsp90 is one of these factors that interact with CYP2E1 and/or with the proteasome to promote the degradation of this microsomal P450 [102].

In the presence of ethanol, only the slower phase of turnover is observed. The half-life of ethanol-stabilized CYP2E1 was calculated at $38 \mathrm{~h}$ [111]. CYP2E1 substrates specifically inhibited the rapid intracellular degradation of CYP2E1 and also prevented phosphorylation and subsequent proteolysis in isolated microsomes. Subsirates specific for the enzyme, such as ethanol and imidazole bind with enzyme, protect the enzyme from cAMP-dependent phosphorylation Ser129 and from degradation in hepatocytes $[91,102,112]$. It is suggested that CYP2E1 is acutely inactivated in the endoplasmic reticulum and that degradation of this isozyme occurs, at least in part, by the lysosomal route. 
In conclusion, CYP2E1 is of interest because of its ability to metabolize and activate many toxicological substrates, including ethanol. Levels of CYP$2 \mathrm{E} 1$ are significantly elevated by specific substrates and under a variety of pathophysiological conditions. CYP2E1 induction enhances the toxicity and carcinogenicity of many xenobiotics. Moreover, CYP2E1 is one of the major hepatic enzymes involved in the metabolism of procarcinogens. Therefore, investigations of CYP2E1 expression and functional activity are of particular importance.

\section{I. М. Дакко, М. О. Чащик}

Структурно-функціональна харахтеристиха цитохрому Р4502E1 (CYP2E1)

Pезкоме

В огляді узагальнено реэультати дослідження рібня експресій $i$ локалізацї, структурц і фунхціональних өластияостей цито Хрому P4502EI (СYP2EI). Роздлянуто механізки індукції синтезу l ахтияності СYP2E1 різники за хімічною структурою смолуками, а тахож за деяких патофізіологінних станів організму. Значну увагу приділено індібіторам ехспресй СYP2EI. Проснатізовано останні дані відносно механізмів ресу-

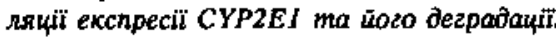

Krюrosi crosa: цитохром P4502EI (CYP2E1), exсnpecir, індуктори та інаібітори, ресуляція ехспресй, охисний метабorizм emanory.

К. М. Данко, Н. А. Чаицин

Структурно-функциональная харахтеристика цитохрома P4502E1 (CYP2E1)

\section{Резюме}

В обжоре обобщены результаты исследования уровна экспрессии и rокализации, смруктуры и функционатьньх свойсть цитохрома P4502EI (CYP2EI). Рассмотрень механизмы индукцин синтеза и активности СУР2EI различнени по хинической структуре соединениями, а такхе при некоторых патофизиологических состояниях организма. Знаительное внимание уделено икеибиторам экспрессии СРР2Е1. Проанализировакы последние данные относительно неханизмо регуняиии экспрессии CYP2EI и еzо деzредаииu.

Ключеөbе слова: цитохром P4502EI (CYP2E1), экспрессия, индукторы и шнгибиторы, регуляция экспресси, окислительный метаболизм этанола.

\section{REFERENCES}

1. Anzenbacher $P$, Anzenbacherova E. Cytachromes $P 450$ and metabolism of xenobiotics // Cell Mol. Life Sci.-2001.-58.P. 737-747.

2. Umeno M., McBrida $O$. W., Yang Ch S., Gelboin $H . V$, Gonzalez $J$. Human ethanol-inducible H450 11E1: Complete gene sequence, promoter characterization, chromosome mapping, and cDNA-directed expression // Biochemistry.1988.-27.-P. 9006-9013.

3. Horada $S$. Classification of alcohol metabolizing enzymes and polymorphisms specificity in Japanese // Nihon Arukoru Yakubutsu lgakkai Zasshi.-2001.-36.-P. 85-106.
4. Lewis D. F., Bird M. G., Dickins M., Lake B. G., Eddershaw P. J., Tarbit M. H., Goldfarb P. S. Moleculat modelling of human CYP2E1 by homology with the CYP102 haemoprotein domain: investigation of the interactions of substrates and inhibitors within the putative active site of the human CYP2E1 isoform // Xenobiotica.-2000, -30,-P. 1-25.

5. Lee S. S., Buters J. T., Pineou T., Fernandez-Salguero P., Gonzalez $F$. $J$. Role of CYP2E1 in the hepatotoxicity of acetaminophen // J. Biol. Chem.-1996.-271.-P. 1206312067 .

6. Song B. J., Gelboin H. V., Park S. S., Yang C. S., Gonzalez F. $J$. Complementary DNA and protein sequences of ethanolinducible rat and human cytochrome $P-450 \mathrm{~s}$. Transcriptiona] and post-transcriptional regulation of the rat enzyme // J. Biol. Chem.-1986.-261.-P. 16689-16697.

7. Ingelman-Sundberg $M$., Ronis $M$. $J$, Lindros $K O$., Eliasson E., Zhukov A. Ethanol-inducible cy tochrome P4502E1: regulation, enzymology and molecular biology // Alcohol Alcohol Suppl.-1994.-2.--P. 131-139.

8. Khani S. C., Zaphiropoulos P. G., Fujita V. S., Porter T, D. cDNA and derived amino acid sequence of ethanol-inducibie rabbit liver cytochrome P-450 isozyme 3a (P-450) // Proc. Nat. Acad. Sci. USA. -1987.-84.-P. 638-642.

9. Данко И. М., Одынец К А., Китам В. О., Уащин Н. А. Комльютерное моделирование пространственной структуры цитохрома Р450 2E1 // Укр. биохим. журн.-2006.78, № 2.-C. $80-88$.

10. Park $J$. Y., Harris $D$. Construction and assessment of models of CYP2E1: predictions of metabolism from docking, molecular dynamics, and density functional theoretical calculations // J. Med. Chem.-2003.-46. -P. 1645-1660.

11. Lewis D. F., Like B. G., Bird M. G., Loizon G. D., Dickins M., Goldfarb P. S. Homology modelling of human CYP2EI based on the CYP2C5 crystal structure: investigation of enzyme-substrate and erizyme-inhibitor interactions // Toxicol. In Vitro.-2003.-17,-P. 93-105.

12. Tan Y., White S. P., Paranawithana S. R., Yang C. S. A hypothetical model for the active site of human cytochrome P4502E1 // Xenobiotica.-1997.-27.-P. 287-299.

13. Mackman R., Guo Z., Guengerich F. P., de Montellano O. P. R. Active site topology of human cytochrome P450 2E1// Chem. Res. Toxicol.-1996.-9.-P. 223-226.

14. Lewis D. F. Homology modelling of human CYP2 family enzymes based on the CYP2C5 crystal structure // Xenobiotica.-2002.-32.-P. 305-323.

15. Banerjee A., Kocarek T. A., Novak R. F. Identification of a ubiquitination-Target/Substrate-interaction domain of cytochrome P-450 (CYP) 2E1 // Drug Metab. Dispos. - 2000.28.-P. $118-124$.

16. Johansson $I$, Lindros $K$ O., Eriksson H., Ingelman-Sundberg $M$. Transcriptional control of CYP2E! in the perivenous liver region and during starvation // Blochem. and Biophys. Res. Communs. $-1990 .-173,-P$. 331-338.

17. Tanaka E., Terada M., Misawa S. Cytochrome P450 2E!: its clinical and toxicological rote // J. Clin. Pharm. Ther.2000.-25. -P. 165-175.

18. Nishimura M., Yaguti H., Yoshitsugu H., Naito S., Satoh T. Tissue distribution of mRNA expression of human cytochrome P450 isoforms assessed by high-sensitivity real-time reverse transcription PCR // Yakugaku Zasshi.-2003.--123.P. $369-375$.

19. Zerill A., Lucas D., Amet Y., Beauge F., Volant A., Floch $H$. H., Berthou F., Menez J. F. Cytochrome P-450 2E1 in rat liver, kidney and lung microsomes after chronic administration 
of ethanol either orally or by tuhalation // Alcohol Alcohol.1995.-30.-P. 357-365.

20. Lechevrel M., Casson A. G., Wolf C. R., Hardie L J., Flinterman $M$. B., Montesano $R$, Wild C. P. Characterization of cytochrome $\mathbf{P} 450$ expression in human oesophageal mucosa // Carcinogenesis.-1999.-20.-P. 243-248.

21. Runge D. M., Stock T. W., Lehmann T., Taege C., Bernauet $U$., Stolz D. B., Hofmann S., Foth $H$. Expression of cytochrome P450 2E1 in normal human bronchial epithelial cells and activation by ethanol in culture // Arch. Toxicot-2001, -75.-P. 335-345.

22. Ding $X$. Kaminsky $L$. S. Human extrahepatic cytochromes P450: function in xenoblotic metabolism and tissue-selective chemical toxicity in the respiratory and gastrointestinal tracts $/ /$ Annu. Rev. Pharmacol. Toxicol. $-2003 .-43 .-P, 149-$ 173.

23. Waxman D. J., Morrissey J. J., LeBlanc G. A. Femalepredominant rat hepatic P-450 forms $j$ (IIEI) and 3 (IIAl) are under hormonal regulatory controls distinct from those of the sex-spectfic P-450 forms // Endocrinology.-1989.-124.P. 2954-2966.

24. Dicker E., Cederboum A. I. Increased oxidation of dimethylnitrosamine in pericentral microsomes after pyrazole induction of cytochrome P-4502E1 // Alcohol Clin. Exp. Res.--1991.15.-P. $1072-1076$.

25. Ingelman-Sundberg $M$., Johansson $I$., Penttila $K$. E, Glaumann $H$., Lindros $K O$. Centrilobular expression of ethanolinducible cytochrome P-450 (IIE1) in rat liver // // Bjochem. and Biophys. Res. Communs.-1988.-157.-P. 55-60.

26. Takahashi $T$., Lasker J. M., Rosman A. S., Lieber C. S. Induction of cytochrome $\mathrm{P}-4502 \mathrm{EI}$ in the human tiver by ethanol is caused by a corresponding increase in encoding messenger RNA // Hepatology.-1993.-17.-P. 236-245.

27. Lieber $C$. $S$. The discovery of the microsomal ethanol oxidizing system and its physiologic and pathologic role // Drug Metab. Rev. $-2004 .-36 .-P .511-529$.

28. Ronis M. J., Johansson I., Hultenby $K$, Lagercrantz J., Glaumonn $H$., Ingelman-Sundberg $M$. Acetone-regulated synthesis and degradation of cytochrome $P 450 \mathrm{El}$ and cytochrome P4502B1 in rat liver [corrected] // Eur. J. Biochem.-1991._. 198.-P. 383-389.

29. Wu D., Cederbaum $A$. 1 . Presence of functionally active cytochrome P-450llEl in the plasma membrane of rat hepatocytes // Hepatology. $-1992 .-15 . \rightarrow P .515-524$.

30. Gonzalez $F, J$. Role of cytochromes $\mathrm{P} 450$ in chemical toxicity and oxidative stress: studies with CYP2El // Mutat. Res.2005.-569.-P. 101-110.

31. Lucas D., Ferrara R., Gonzales E., Albores A., Manno M., Berthou $F$. Cylochrome CYP2E1 phenotyping and genotyping in the evaluation of health risks from exposure to polluted environments // Toxicol. Lett. $-2001 .-124 .-P .71-81$.

32. Guengerich $F$. P. Metabolism of chemical carcinogens // Carcinogenesis. $-2000 .-21$.-P. 345-351.

33. Guengerich $F, P$. Common and uncommon cytochrome $P 450$ reactions related to metabolism and chemical toxicity $/ /$ Chem. Res. Toxicol.-2001.-14.-P. 611-650.

34. Bell-Parikh $L$. C., Guengerich F. $P$. Kinetics of cytochrome P450 2El-catalyzed oxidation of ethanol to acetic acid via acetaldehyde // J. Biol. Chem.-1999.-274,..-P. 2383323840.

35. Banerjee S., Shang T. Q, Witson A. M., Moore A. L., Strand S. E., Gordon M. P., Lafferty Doty S. Expression of functional mammalian P450 2E1 in hairy root cultures // Biotechnol. Bioeng. $-2002,-77,-$ P. $462-466$.
36. Burim R. V., Canalle R., Ade M. L., Takahashi C. S. Polymorphisms in glutathione S-transferases GSTM1, GSTT1 and GSTP1 and cytochromes P450 CYP2E1 and CYPIA1 and susceptibility to cirrhosis or pancreatitis in alcoholics // Mutagenesis.-2004-19.-P. 291-298.

37. Lieber C. S., DeCarli L. M. Hepatic microsomal ethanoloxidizing system. In vitro characieristics and adaptive properties in vivo // J. Biol. Chem.-1970.-245.-P. 2505-2512.

38. Novak $R, F$, Woodcroft $K J$. The alcohol-inducible form of cytochrome P450 (CYP 2E1): role in toxicology and regulation of expression // Arch. Pharm. Res. -2000.-23.-P. 267282.

39. Valentine J. L., Lee $S . S$, Seaton M. J., Asgharian B., Farris G., Corton J. C., Gonzalez F, J., Medinsky M. A. Reduction of benzene metabolism and toxicity in mice that lack CYP2EI expression // Toxicol. Appl. Pharmacol.-1996.-141.P. 205-213.

40. Kessova I., Cederbaum A. I. CYP2EI : biochemistry, 10xicology, regulation and function in ethanol-induced liver injury $/ /$ Curr. Mol. Med.-2003.-3.-P. 509-5!8.

41. Yamazaki H., Inui Y., Yun C. H., Guengerich F. P., Shimada $T$. Cytochrome P450 2E! and $2 A 6$ enzymes as major catalysts for metabolic activation of $\mathrm{N}$-nitrosodialkylamines and tobaccorelated nitrosamines in human liver microsomes // Carcinogenesis.-1992.-13.-P. 1789-;794.

42. Patten C. J., Smith T. J., Murphy S. E., Wang M. H., Lee J., Tynes $R$. E., Koch $P$., Yang $C$. $S$. Kinetic analysis of the activation of 4-(methylnitrosamino)-1-(3-pyridyl)-1-butanone by heterologously expressed human $P 450$ enzymes and the effect of P450-specific chemical inhibitors on this activation in human liver microsomes // Arch. Biochem, and Biophys.1996.-333.-P. $127-138$.

43. Bellec G., Goasduff T., Dreano Y, Menez J. F., Berthou F. Effect of the length of alkyl chain on the cytochrome P450 dependent metabolism of $\mathrm{N}$-dialkylnitrosamines $/ /$ Cancer Lett.-1996.-100.-P. 115-123.

44. Yoo J. S., Guengerich F. P., Yang C. S. Metabolism of $\mathrm{N}$-nitrosodialkylamines by human liver microsomes // Cancer Res. - 1988.-48.-P. 1499-1504.

45. Gan J., Skipper P. L, Tannenbaum S. R. Oxidation of 2,6-dimethylaniline by recombinant human cytochrome P450s and human liver microsomes // Chem. Res. Toxicol.-2001.14.-P. 672-677.

46. Wang H., Chanas B., Ghanayem B. I. Cytochrome P450 2E1 (CYP2E1) is essential for acrylonitrile metabolism to cyanide: comparative studies using CYP2E1-null and wild-type mice // Drug Metab. Dispos.-2002.-30.-P. 911-917.

47. Adas F., Salatun J. P., Berthou F., Picart D., Simon B., Amet $Y$. Requirement for omega and (omega;-1)-hydroxylations of fatty acids by human cytochromes P450 2E1 and 4A11// J. Lipid Res. -1999.-40.-P. 1990-1997.

48. Amato G., Grasso E., Longo V., Gervasi P. G. Oxidation of $\mathrm{N}, \mathrm{N}$-dimethylformamide and $\mathrm{N}, \mathrm{N}$-diethylformamide by human liver microsomes and human recombinani P450s // Toxicol. Lett.-2001.-124.-P. $11-19$.

49. Kapucuoglu N., Coban $T$, Raunio $H$., Pelkonen O., Edwards R. $J$, Boobis A. R., Iscan M. Immunohistochemical demonstration of the expression of CYP2EI in human breast tumour and non-tumour tissues // Cancer Lett.-2003.-196.-P. 153159.

50. Aviram M., Kent U. M., Hollenberg P. F. Microsomal cytochromes P450 catalyze the oxidation of low density jipoprotein // Atherosclerosis. - 1999.-143.-P. 253-260.

51. Meskar A., Plee-Gautier E., Amet Y., Berthou F., Lucas D. 
Alcohol-xenobiotic interactions. Role of cytochrome P450 2E1 // Pathol. Biol. (Paris),-2001.-49.-P. 696-702.

52. Walubo A., Barr S., Abraham A. M., Coetsee C. The role of cy tochrome-P450 inhibitors in the prevention of hepatotoxicity after paracetamol overdose in rats // Drug Metab. Dispos.2004.-23.-P. 49-54.

53. Bessems J. G., Vermeulen N. P. Paracetamol (acetaminophen)-induced toxicity: molecular and biochemical mechanisms, analogues and protective approaches $/ /$ Crit. Rev. Toxicol.-2001.-31.-P. 55-138.

54. Halmes N. C., Samakyszyn V. M., Hinton T. W., Hinson J. A., Pumford N.R. The acetaminophen regioisomer 3'-hydroxyacetanilide inhibits and covalently binds to cytochrome $\mathbf{P 4 5 0}$ 2E1 // Toxicol. Lett.-1998.-94.--P. 65-71.

55. Spracklin D. K. Emery M. E., Thummet K. E., Kharasch E. $D$. Concordance between trifluoroacetic acid and hepatic protein trifluoroacetylation after disulfiram inhibition of halothane metabolison in a rats // Acta Anaesthesiol. Scand.2003.-47.-P. 765-770.

56. Zhao P., Kalhorn T. F., Slattery $J$. T. Selective mitochondria] giutathione depletion by ethanol enhances acetaminophen toxicity in rat liver // Hepatology.-2002.-36.-P. 326-335.

57. Takahashi S., Takahashi T., Mizobuchi S., Matsumi M., Morita K., Miyazaki M., Namba M., Akagi R., Hirakawa M. Increased cytotoxicity of carbon tetrachloride in a humant hepatoma cell lise overexpressing cytochrome $\mathbf{P} 4502 \mathrm{El} / / \mathrm{J}$. Int. Med. Res, $-2002 .-30,-$-P. 400-405.

58. Wong F. W., Chan W. Y., Lee.S. S. Resistance to carbon tetrachloride-induced hepatotoxicity in mice which lack CYP2E1 expression // Toxicol. Appl. Pharmacol.-1998._153.P. 109-118.

59. Boll M., Weber LW., Becker E., Stampfl A. Mechanism of carbon tetrachloride-induced hepatotoxicity. Hepatocellular damage by reactive carbon tetrachloride metabolites $/ / \mathrm{Z}$. Naturforsch. [C].-2001.-56.-P. 649-659.

60. Weber $L, W$, Boll M., Stampfl $A$. Hepatotoxicity and mechanism of action of haloalkanes: carbon tetrachloride as a toxicological model // Crit. Rev. Toxicol.-2003.-33.P. $10-36$.

61. Ekstrom G., von Bahr C., Ingelman-Sundberg $M$. Human liver microsomal cytochrome P-450IIE1. Immunological evaluation of its contribution to microsomal ethanol oxidation, carbon tetrachloride reduction and ADPH oxidase activity // Biochem. Pharmacol. -1989.-38,-P. 689-693.

62. Zhukov A., Ingelman-Sundberg $M$. Relationship between cytochrome P450 catalytic cycling and stability: fast degradation of ethanol-inducible cytochrome P450 2E1 (CYP2E1) in hepatoma cells is abolished by inactivation of its electron donor NADPH-cytochrome P450 reductase // Biochem. J.-1999.340.-P. 453-458.

63. Cederbaum A. I., Wu D., Mari M., Bai J. CYP2E1-dependent toxicity and oxidative stress in HepG2 cells // Free Radic. Biol. Med.-2001.-31.-P. 1539-1543.

64. Kalapos $M$. $P$. On the mammalian acetone metabolism: from chemistry to clinical implications // Biochim. et Biophys. Acta.-2003.-1621.-P. 1122-1139.

65. Bondoc F. Y., Bao Z., Hu W. Y., Gonzalez F. J., Wang Y., Yang $C$. S., Hong $J$. $Y$. Acetone catabolism by cytochrome P450 2E1: studies with CYP2E1-null mice // Biochem. Pharmacol.-1999.-58.-P. 461-463.

66. Amet Y., Adas F., Nanji A. A. Fatty acid omega- and (omega-1)-hydroxylation in experimental alcoholic liver disease: relationship to different dietary fatty acids // Alcohol Clin. Exp. Res.-1998.-22.-P. 1493-1500.
67. Coon $M . J$. Enzyme ingenuity in biological oxidations: a trail leading to cytochrome p450 // J. Biol. Chem.-2002.-277.P. $28351-28363$.

68. Monostory $\mathcal{X}$, Hazai E., Vereczkey $L$ Inhibition of cytochrome P450 enzymes particlpating in p-nitrophenol hydroxylation by dnus known as CYP2E1 inhibitors // Chem. Biol. Interact.2004.-147.-P. 331-340.

69. Wolf $\mathcal{K}$ K., Wood S. G., Bement J. L, Sinclair P. R., Wrighton S. A., Jeffery E., Gonzalez F. J., Sinclair J. F. Role of mouse CYP2E1 in the O-hydroxylation of p-nitrophenol: comparison of activities in hepatic microsomes from Cyp2el (/-) and wild-type mice // Drug Metab. Dispos.-2004,-32.P. $681-684$.

70. Park K S., Sohn D. H., Veech R. L. Song B. J. Translational activation of ethanol-inducible cytochrome P450 (CYP2E1) by isoniazid // Eur. J. Pharmacol.-1993.-248.-P. 7-14.

71. Peter R., Bocker R., Beaune P. H., Jwasaki M., Guengerich F. $P$, Yang $C$. $S$. Hydroxylation of chlorzoxazone as a specific probe for human liver cytochrome P-450IIE1// Chem. Res. Toxicol.-1990.-3.-P. 566--573.

72. Chen T. L, Chen T. G., Tai Y. T., Chang H. C., Chen R. M., Lin C. J., Ueng T. $H$. Propofol inhibits renat cytochrome P450 activity and enflurane defluorination in vitro in hamsters // Can. J. Anaesth.-2000.-47.-P. 680-686.

73. Bolt H. M., Roos P. H., Thier R. The cytochrome P-450 iscenzyme CYP2El in the biological processing of industria] chemicals: consequences for occupational and environmental medicine $/ /$ Int. Arch. Occup. Environ. Health. $-2003 .-76 .-$ P. 174-185.

74. Amato G., Longo V., Mazzaccaro A., Gervasi P. G. Chlorzoxazone 6-hydroxylase and p-nitrophenol hydroxylase as the most suitable activities for assaying cytochrome P450 2E1 in cynomolgus monkey liver // Drug Metab. Dispos.-1998.26. -P. $483-489$.

75. Sncuder J. E., Lipscomb $J$. C. Interindividuat variance of cytochrome P450 forms in human hepatic microsomes: correlation of individual forms with xenobjotic metabolism and implications in risk assessment // Regul. Toxicol. Pharmacol.2000.-32.-P. 200-209.

76. Hu $Y$., Hakkola $J$, Oscarson $M$, Ingelman-Sundberg $M$. Structural and functional characterization of the 5 -flanking region of the rat and human cytochrome P450 2E1 genes: Identification of a polymorphic repeat in the human gene $/ /$ Biochem. and Biophys. Res. Communs.-1999.-263.P. $286-293$.

77. Chen X. P., Han X. M., Jiang C. H., Huang S. L., Liu Z. Q., Zhu B., Zhou G., Zhou H. H. Phenotype distribution and gender-related differences of CYP2E1 activity in a Chinese population // Xenobiotica.-2002.-32.-P. 1053-1062.

78. Powell H., Kitteringham N. R., Pirmohamed M., Smith D. A., Park $B$. $K$ Expression of cytochrome P4502E1 in human liver: assessment by mRNA, genotype and phenotype // Pharmacogenetics. - 1998.-8.-P. 411-421.

79. $\operatorname{Kim} R$. B., $O$ 'Shea $D$. Interindividual variability of chlor zoxazone 6-hydroxylation in men and women and its relationship to CYP2El genetic polymorphisms // Clin. Pharmacol. Ther.-1995.-57.-.P. 645-655.

80. McCarver D. G., Byun R., Hines R. N., Hichme M., Wegenek $W$. A genetic polymorphism in the regulatory sequences of human CYP2E1: association with increased chlorzoxazone hydroxylation in the presence of obesity and ethanol intake // Toxicol. Appl. Pharmacol.-1998.-152.-P. 276-281.

81. Marchand L. L, Wilkinson G. R., Wilkens L R. Genetic and dietary predictors of CYP2E1 activity: a phenotyping study in 
Hawaii Japanese using chlorzoxazone // Cancer Epidemiol. Biomarkers Prev. - 1999.-8.-P. 495-500.

82. Kim R. B., Yamazaki H., Chiba K., Orshea D., Mimura M., Guengerich F. P., Ishizaki T., Shimada T., Wilkinson G. $\boldsymbol{R}$. In vivo and in vitro characterization of CYP2E1 activity in Japanese and Caucasians // J. Pharmacol. Exp. Ther.1996.-279.-P. 4-11.

83. Poland R. A., Lin K M., Nuccio C., Wilkinson G. $R$. Cytochrome P450 2E1 and $3 \mathrm{~A}$ activities do not differ between Mexicans and European Americans // Clinn. Pharmacol. Ther.-2002.-72.-P. $288-293$.

84. Simi A., Ingelman-Sundberg $M$. Post-translational inhibition of cytochrome P-450 2E1 expression by chlormethiazole in Fao hepatoma cells // J. Pharmacol. Exp. Ther.-1999.-289.P. $847-852$.

85. Ohashi Y., Yamada $K$, Takemoto I., Mizutani T., Saekl $K$. Inhibition of human cytochrome P450 2E1 by halogenated anilines, phenols, and thiophenols // Biol. Pharm. Bull.2005.-28.-P. 1221-1223.

86. Wargovich $M, J$. Diallylsulfide and allylmethylsulfide are uniquely effective among organosulfur compounds in inhibiting CYP2El protein in animal models // J. Nutr.-2006.-136.P. $8325-834 S$.

87. Yang C. S., Chhabra S. K, Hong J. Y., Smith T. J. Mechanisms of inhibition of chemical toxicity and carcinogenesis by dialiyl sulfide (DAS) and related compounds from garlic // J. Nutr.-2001.-131.-P. 1041S-1045S.

88. Hu Y., Mishin V., Johansson I., von Bahr C., Cross A., Ronis M. J., Badger $T$. M., Ingelman-Sundberg $M$. Chlormethiazole as an efficient inhibitor of cytochrome $\mathrm{P} 450 \mathrm{2E} 1$ expression in rat liver // J. Pharmacol. Exp. Ther.-1994.-269.P. $1286-1291$.

89. Hakkola J., Hu Y., Ingelman-Sundberg $M$. Mechanisms of down-regulation of CYP2E1 expression by inflammatory cytokines in rat hepatoma cells // J. Pharmacol. Exp. Ther.2003.-304.-P. 11048-11054.

90. Eliasson E., Johansson I., Ingelman-Sundberg M. Ljgand-dependent maintenance of ethanol-inducible cytochrome P-450 in primary rat hepatocyte cell cultures // Biochem. and Biophys. Res. Communs.-1988.-150.-P. 436-443.

91. Song B. J., Veech R. L., Park S. S., Gelboin H. V., Gonzalez $F$. $J$. Induction of rat hepatic N-nitrosodimethylamine demethylase by acetone is due to protein stabitization // J. Biol. Chem.-1989.-264,--P. 3568-3572.

92. Woodcroft $K$ J., Novak $R$. F. Insulin differentially affects xenoblotic-enhanced, cytochrome P-450 (CYP)2E1, CYP2B, CYP3A, and CYP4A expression in primary cultured rat hepatocytes // J. Pharmacol. Exp. Ther.-1999.-289.P. $1121-1127$.

93. Kim S. G., Novak $\boldsymbol{R}$. F. Induction of rat hepatic P450IEL1 (CYP 2E1) by pyridine: evidence for a role of protein synthesis in the absence of transcriptional activation // Biochem. and Biophys. Res. Communs.-1990.-166.-P. 10721079.

94. Brown B. L, Allis J. W., Simmons J. E, House D. E. Fasting for less than $24 \mathrm{~h}$ induces cytochrome P450 2E1 and 2B1/2 activities in rats // Toxicol. Lett. -1995.-81.-P. 39-44.

95. Lucas D., Menez C., Girre C., Berthou F., Bodenez P., Joannet I., Hispard E., Bardou L. G., Menez J. F. Cytochrome P450 2E1 genotype and chlorzoxazone metabolism in healthy and alcoholic Caucasian subjects // Pharmacogenetics.-1995.-5.-P. $298-304$.

96. Woodcroft $K$ J., Hafner M. S., Novak R. F. Insulin signaling in the transcriptional and posttranscriptional regulation of
CYP2E1 expression // Hepatology.-2002.-35.-P. 263273.

97. Wang Z., Hall S. D., Maya J. F., Li L., Asghar A., Gorski J. C. Diabetes mellitus increases the in vivo activity of cytochrome P450 2E! in humans $/ / \mathrm{Br}$. J. Clin. Pharmacol.-2003.55.-P. 77-85.

98. Yun Y. P., Casazza J. P., Sohn D. H., Veech R. L, Song B. $J$. Pretranslational activation of cytochrome P450IIE during ketosis induced by a high fat diet // Mol. Pharmacol.1992.-41.-P. 474--479.

99. Woodcroft $K$ J., Novak $R$. F. Xenobiotic-enhanced expression of cytochromes P450 2E1 and 2B in primary cultured rat hepatocytes // Drug Metab. Dispos.-1998.--26.-P. 372378.

100. Kocarek $T, A .$, Zangar $R$. C., Novak $R$. F. Post-1ranscriptional regulation of rat CYP2E1 expression: role of CYP2E1 mRNA untransiated regions in control of translational efficiency and message stability // Arch. Biochem. and Biophys.-2000.376.-.P. $180-190$.

101. Ueno $T$., Gonzalez $F$. J. Transcriptional control of the rat hepatic CYP2Ei gene $/ /$ Mol. Cell. Biol.-1990.-10.P. 4495-4505.

102. Goasduff T., Cederbaum A. I. CYP2E1 degradation by in vitro reconstituted systems: role of the molecular chaperone hsp90 // Arch. Biochem. and Biophys,-2000.-379.P. $321-330$.

103. Morishima Y., Peng H. M., Lin H. L., Hollenberg P. F., Sunahara $R . K$, , Osawa $Y$. Pratt $W, B$. Regulation of cytochrome P450 2E1 by heat shock protein 90-dependent stabilization and CHIP-dependeni proteasomal degradation // Biochemistry.-2005.-44.-P. 16333-16340.

104. Son M. H., Kang K. W., Kim E. J., Ryu J. H., Cho H., Kim S. H., Kim W. B., Kim S. G. Role of glucose utilization in the restoration of hypophysectomy-induced hepatic cytochrome P450 2E1 by growth hormone in rats // Chem. Biol. Interact. $-2000 .-127 .-$ P. $13-28$.

105. Chen G. F., Ronis M. J., Ingelman-Sundberg M., Badger $T$. $M$. Hormonat regulation of microsomal cytochrome P4502E1 and P450 reductase in rat liver and kidney // Xenoblotica.1999.-29.-P. 437-451.

106. Kunitoh S., Imaoka S., Hirot T., Yabusaki Y., Monna T., Funae $Y$. Acetaldehyde as well as ethanol is metabolized by human CYP2E1 // J. Pharmacol. Exp. Ther.-1997.-280.P. 527-532.

107. Tsutsumi M., Lasker J. M., Takahashi T., Lieber C. S. In vivo Induction of hepatic P4502E1 by ethanol: role of increased enzyme synthesis // Arch. Biochem. and Biophys.-1993.304,-P. 209-218.

108. Lu Y., Cederbaum A. I. Cisplatin-induced hepatotoxicity is enhanced by elevated expression of cytochrome P450 $2 \mathrm{El} / /$ Toxicol. Sci.-2006.-89.-P. 515-523.

109. Badger T. M., Huang J., Ronis $M$., Lumpkin C. $K$ Induction of cytochrome P450 2E1 during chronic ethanol exposure occurs via transcription of the CYP 2El gene when blood alcohol concentrations are high // Biochem, and Btophys. Res. Communs.-1993.-190.-P. 780-785.

110. Ronis M. J., Huang J., Crouch J., Mercado C., Irby D., Valentine C. R., Lumpkin C. K., Ingelman-Sundberg $M$., Badger T. $M$. Cytochrome P450 CYP 2El induction during chronic alcohol exposure occurs by a two-step mechanism associated with blood alcohol concentrations in rats $/ / \mathrm{J}$. Pharmacol. Exp. Ther-1993.-264-P. 944--950.

111. Roberts $B, J$. Evidence of proteasome-mediated cytochrome 
P-450 degradation $/ /$ J. Btol. Chem.-1997.-272.P. $9771-9778$.

Eliasson E., Mkrtchian S., Ingelman-Sundberg M. Hormoneand substrate-regulated intracellular degradation of cytochrome P450 (2E1) involving MgATP-activated rapid proteolysis in the endoplasmic reticuluf membranes // J. Biol. Chem.-1992.267.-P. 15765-15769.

Rogers S., Wells R., Rechsteiner $M$. Amino acid sequences common to rapidly degraded protetus: the PEST hypothesis // Science.-1986.-234.-P. 364-368.

Oesch-Bartlomowicz B., Padma P. R., Becker R, Richter B., Hengstler J. G., Freeman J. E., Wolf C. R., Oesch F. Differential modulation of CYP2El activity by CAMP-dependent protein kinase upon Ser 129 replacement // Exp. Cell Res.-1998.-242.-P. 294-302.

Zhukav A., Werlinder V., Ingelman-Sundberg M. Purification and characterization of two membrane bound serine proteinases from rat liver microsomes active in degradation of cytochrome P450 // Biochem, and Biophys. Res. Communs.-1993.197.-P. 221-228.

Wong H. F, Pereira F. M. E., Correia $M$. A. Cytochrome P450 3A degradation in isolated rat hepatocytes: 265 pro- teasome inhibitors as probes // Arch. Biochem, and Brophys.1999.-365.-P. $45-53$.

117. Fisher E. A., Zhou M., Mitchell D. M., Wu X., Omura S., Wang H., Goldberg A. $L$, Ginsberg $H$. N. The degradation of apolipoprotein $B 100$ is mediated by the ubiquitin-proteasome pathway and involves heat shock protein $70 / / \mathrm{J}$. Biol. Chem.-1997.-272.-P. 20427-20434.

118. Huan J. Y., Streicher J. M., Bleyle $L$ A, Koop $D . R$. Proteasome-dependent degradation of cytochromes P450 2E1 and $2 \mathrm{BI}$ expressed in tetracycline-regulated Hela cells // Toxicol. Appl. Pharmacol.-2004.-199.-P. 332-343.

119. Bardag-Gorce F., Li J., French B. A., French S. W. Eihanol withdrawal induced CYP2E1 degradation in vivo, blocked by proteasomal inhibitor PS-341 // Free Radic. Biol. Med.2002.-32. -P. 17-21.

120. Hayes $S$. A., Dice $J$. F. Roles of molecular chaperones in proteln degradation // J. Celi Biol.-1996.-132.-P. 255258.

УДК $612.014 .482: 577.158 .83$

Надійшла до редакції 30.10 .06 